\title{
Artificial infiltration as an integrated water resources management tool
}

\author{
Z. Boukalová ${ }^{1,2}$, J. Těšitel ${ }^{3}$, Z. Hrkal $^{4}$ \& D. Kahuda ${ }^{5}$ \\ ${ }^{1}$ VODNÍ ZDROJE, a.s., Czech Republic \\ ${ }^{2}$ Department of Physical Geography and Geoecology, \\ Faculty of Sciences, Charles University, Czech Republic \\ ${ }^{3}$ University of South Bohemia, Czech Republic \\ ${ }^{4}$ T.G. Masaryk Water Research Institute, Czech Republic \\ ${ }^{5}$ GIS GEOINDUSTRY, s.r.o., Czech Republic
}

\begin{abstract}
In recent years, water shortages have become an increasing concern, with a growing imbalance between water demand and availability reaching critical levels in the world. Managed aquifer recharge incorporated to integrated water resource management (IWRM) is an effective solution to this challenge and could assure sufficient water supply in the local or regional scale, for all the end users. The main objective of the paper is the presentation of different technologies of artificial infiltration that could be incorporated in the process of integrated water resource management at a local scale, where competing demands of different users and stakeholders can be communicated and managed effectively.

The paper is based on the research related to the project PROTĚŽ (Development of advanced technology for environmental protection and incorporation of this knowledge into new tools for better-integrated water management in the catchment scale) and the EUREKA project STORAGE (Sustainable TOols for gRoundwater manAGEment optimisation and water scarcity mitigation).

Keywords: groundwater, integrated water resources management, rainwater harvesting, monitoring, Czech Republic, Nepal.
\end{abstract}




\section{Introduction}

In recent years, water shortages have become an increasing concern, with a growing imbalance between water demand and availability reaching critical levels in many parts of Europe and globally. Although Europe is considered a continent with sufficient water resources, $17 \%$ of the territory (corresponding to $11 \%$ of the population) is affected by water scarcity; the number of areas and people affected by droughts increased by almost $20 \%$ in the past 30 years; $60 \%$ of European citizens over-exploit water resources; and 20 million people in Central and Eastern Europe still do not have access to basic sanitation. The situation is worst outside of Europe, for example in Asia. The artificial infiltration (managed aquifer recharge) incorporated to integrated water resource management is an effective solution of this challenge and could assure sufficient water supply in the local or regional scale, for all end users.

Artificial infiltration of water into the aquifer is used to create a water supply at a time of excess water for times of water shortage, it is used to reduce the depletion of groundwater, thereby preventing subsequent ground surface subsidence, it helps to create a hydraulic barrier against the ingress of seawater and against the movement of contamination plumes and may also provide wastewater treatment for reuse, particularly for drinking purposes and unlimited irrigation. Infiltration of conventionally treated wastewater (primary and secondary treatment followed by slight chlorination) and subsequent controlled substitution of depleted groundwater is increasingly carried out in the world, in order to improve the quality of treated wastewater by passing through the aquifer or increase groundwater supply for subsequent use. This water can then be used for various purposes, such as irrigation, enhancement of surface waters, and after additional purification or dilution also for drinking purposes.

\section{Two different cases of the artificial infiltration of water}

Infiltration of wastewater into groundwater affects the environment both positively and negatively. Infiltration of treated wastewater is very site specific, and therefore no results can be generalized as a universal tool to use the technology in any environment. Before performing infiltration it is necessary to prepare a detailed study, in which all characteristics of the site in question will be considered, and only then it will be possible to assess any potential environmental risks. In the Czech Republic, so far, any discharge of wastewater into the rock environment has been strictly limited by law and shall be allowed only if the discharged water is treated at a waste water treatment plant and if there is no a nearby watercourse, into which wastewater could be mouthed. Only in exceptional cases the discharge and subsequent infiltration of wastewater is permitted for individual residential buildings and cottages, without treatment (case 1: pilot site $\check{R}$ evničov). Experience has shown that artificial infiltration of wastewater into the geological environment is, under certain conditions, both economically and environmentally acceptable method for strengthening groundwater reserves. 
The situation is different for infiltration of rainwater, where no significant contamination is expected; infiltration of rainwater is very suitable for increasing the capacity of groundwater aquifer especially at sites, where groundwater level falls due to excessive abstractions (case 2: pilot site Patan).

When deciding on a suitable solution for infiltration, the most important criterion is the quality of precipitation surface water and the rock environment into which rainwater can infiltrate. Design and dimensioning of infiltration facility must ensure the protection of buildings or underground transport facilities (including existing) against flooding. Underground infiltration facility must be fitted with ventilation (ventilation piping, openings in the cover or grate) and should be designed with sediment trap. In places with the expected flow of fine sedimentable particles there must be designed a facility for their removal (for example, filtration or settling tank). Ground surface infiltration facility must be designed to allow easy maintenance and must allow escape of animals.

\section{Artificial infiltration on the pilot site Řevničov}

The aim of the work at the site in Řevničov was to verify ecological parameters of technology of infiltration of wastewater into the rock environment in conditions, where groundwater runoff occurs solely in the shallow subsurface aquifer, with no possibility of leakage to deeper zones. The work was aimed at the design, implementation and professional verification of the functioning of the system, which is currently permitted by water authorities in the Czech Republic only in exceptional cases. The system consists of infiltration area, a natural filter comprising soil cover, unsaturated zone and saturated zone of the rock environment, and monitoring sites.

The basis of this technology is simple infiltration facility, through which pretreated wastewater is infiltrated into the unsaturated zone. In the pilot plant it is a set of the following components:

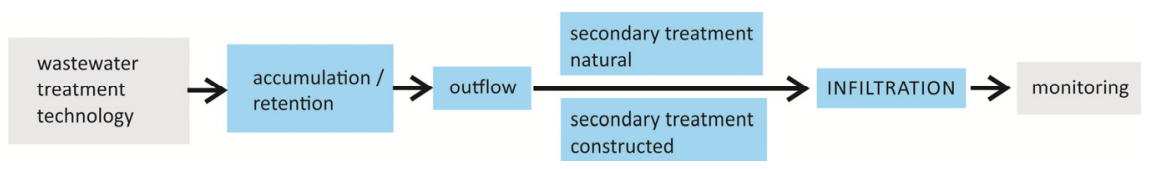

The site is covered with unconsolidated Quaternary sediments, among which colluvial deposits are predominant. Groundwater level in the shallow aquifer in Quaternary sediments and subsurface jointing zone is mostly unconfined, only in areas overlain by less permeable sediments the groundwater level of this aquifer is confined. In terms of the objective of the task, of dominant influence at the site is the shallow aquifer, which is bound to the upper level of Permo-Carboniferous sediments. Groundwater flow in the Quaternary aquifer is generally trending to the local erosion level - to Klíčava (the Leontýnský stream). The deeper aquifer is separated from the upper aquifer by an impermeable clayey layer, which means that this site meets the essential condition of the proposed technology the spread of groundwater in a well-defined, only horizontal direction, the deeper aquifer is not at risk of affecting. 
At the test site a system of monitoring wells was installed which aimed to:

a) determine the natural background beyond the potential impact of contamination

b) enable monitoring of qualitative changes in the saturated zone.

Monitoring sites:

- point of wastewater discharge to the ground ("Waste");

- monitoring well PR drilled to reach a depth of $29 \mathrm{~m}$ below the ground surface at a distance of 100 metres in the direction of groundwater flow from the point of infiltration;

- $\quad$ sampling site close to a culvert below the road connecting the station of Řevničov and the municipality of Lužná, close to the border of nature reserve (site "Klíčava below").

- monitoring well KT situated in a forest beyond the potential impact by infiltration (natural background).

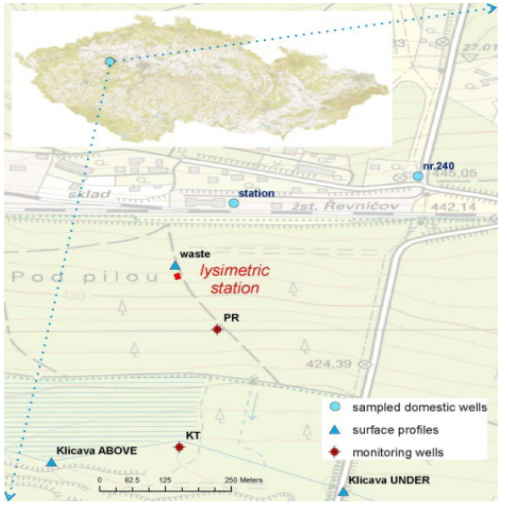

Figure 1: Map of Řevničov pilot site.

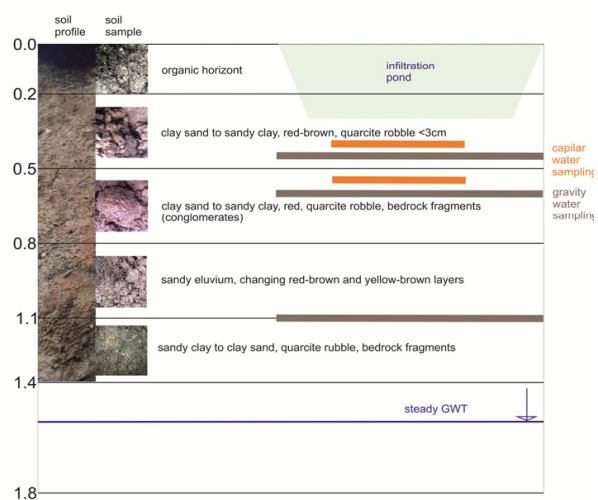

Figure 2: Lysimeter station.

For the purpose of carrying out qualitative monitoring of concentrations of residual contamination in the infiltrated pretreated wastewater, field lysimeter station was installed at the site in Revničov. Its principle is a simulation of flooding infiltration at a constant water level and configuration of sampling sites for sampling of gravity groundwater and capillary groundwater from the unsaturated zone of flow. In the walls of the lysimeter station there were installed triple subhorizontal point probes at a slight slope in a total of 3 levels for sampling of infiltrating subsurface gravity water, with 2 additional levels for sampling of capillary bound water using suction boards. Sampling was carried out continuously, using collection canisters from which at irregular intervals water was sucked for qualitative analyses of selected components for comparison with the results of analyses of samples from monitoring wells. Samples of 
infiltrating waste water are analyzed for the basic chemical and biological components (Escherichia coli, enterococci, coliform bacteria, numbers of colonies at $22^{\circ} \mathrm{C}$ and $36^{\circ} \mathrm{C}$, microscopic image, ammonium ions, nitrates, nitrites, phosphates, $\mathrm{pH}$, dissolved and suspended solids, $\mathrm{COD}_{\mathrm{Cr}}, \mathrm{BSK}_{5}$ ).

Using the above described technical facilities and technologies during the two-year monitoring at the site in Řevničov there were observed qualitative changes that occur in groundwater. The infiltration of untreated wastewater in the rock environment (both in the unsaturated zone and in the upper part of the saturated zone) causes to produce the contamination plume, which is gradually spread in the direction of groundwater flow. It can be assumed that attenuation reactions (i.e. reactions that reduce the total amount, concentration or toxicity of contaminants) occur mainly in the peripheral parts of the plume, where there is mixing of the contamination and background groundwater [1]. It is highly likely that the monitoring wells pass through the entire thickness of the contamination plume which is produced by the infiltration of untreated waste water through the unsaturated zone in the upper part of the water-bearing shallow groundwater aquifer. For this reason, samples collected from existing wells with long perforated sections may not be in chemical equilibrium. The available data, i.e. results of chemical analyses from the monitoring sites KT, PR, "Waste", "Klíčava above" or "Klíčava below", can for this reason be evaluated only at a scale of the entire contamination plume and the individual reaction zones cannot be distinguished. For detailed quantitative evaluation there would be required analytical data with higher spatial resolution, especially in the vertical direction, which would allow us to distinguish between the different zones of the contamination plume.

Results of chemical analyses were compared in terms of both spatial and time trends. The contents of other (potentially reactive) components of interest were compared to chlorides which are not involved in any attenuation reactions and which provide sufficient contrast allowing to distinguish the infiltrated sewage water ("Waste" - approx. $70 \mathrm{mg} / \mathrm{l}$ ) from the background (KT - approx. $14 \mathrm{mg} / \mathrm{l})$. To assess the state of saturation of samples of groundwater and wastewater in relation to the relevant mineral phases, hydrogeochemical model PHREEQC [2] was used. The same programme was used to construct inverse hydrogeochemical model, by means of which the major reactions probably taking place were quantified.

The geochemical processes and concentration trends in the saturated zone were identified with following results:

During the infiltration through sampling points $(0.45 \mathrm{~m}, 0.6 \mathrm{~m}$ and $1.15 \mathrm{~m}$ below surface) nitrification process is significant, where rate of $\mathrm{N}-\mathrm{NO}_{3}$ rises off $\mathrm{N}-\mathrm{NH}_{4}$. Also decomposition of organic residuals is still in progress, represented by other sources of $\mathrm{N}$ and $\mathrm{P}$. In the range of basic chemical components a slight decrease of $\mathrm{Cl}$ and $\mathrm{SO}_{4}$ concentration has been identified, which can be explained by solution in the terms of hypodermic flow. Number of observed fecal bacteria is rapidly decreasing already by penetrating the observed $1.15 \mathrm{~m}$ level especially for coliforms. The biggest drop has been observed at the shallowest topsoil level. 
In all the cases leaching of $\mathrm{Ca}$ and $\mathrm{Mg}$ from the soils has been detected. In case of low intake by plants, $\mathrm{NO}_{3} \mathrm{~S}$ are leaching into groundwater. The fixation of $\mathrm{SO}_{4} \mathrm{~S}$ and $\mathrm{Cls}$ in the soils is insufficient. During the waste water infiltration through a $0,6 \mathrm{~m}$ thick unsaturated layer up to $98 \%$ of $\mathrm{COD}, \mathrm{BOD}_{5}$, ammonia and phosphates have been reduced. A straight dependence between efficiency of bacterial pollution reduction and minimal thickness of unsaturated soils with clay contain was confirmed.

Generally, the evaluation of individual experiments proved the functioning of the pilot plant. The contamination present in wastewater is eliminated by passing through the rock environment to levels that do not endanger the environment. The above described method of infiltration of wastewater can be incorporated into the integrated water management at the site of interest as a sustainable solution and a similar application can be recommended for similar pilot areas.

\section{Possibilities of rainwater recharge in Patan}

Patan is the second largest city in Kathmandu Valley encompassing $15,43 \mathrm{~km}^{3}$ area, inhabited by 220,802 population, (National Population and Housing Census, 2011) that is now facing serious water problems. The original, historical water supply system for Patan consisted of the following main components: distant source of water (the Lele River), which was connected through the Royal Canal with the system of artificial ponds (pokhari) and mouthed in Lagankhel, in the water source area for the whole of Lalitpur. Pokhari - i.e. man-made water bodies, served in Patan for water storage and for infiltration: their bottoms allowed infiltration of surface water into shallow groundwater aquifers that saturated local dug wells (tun) and fountains/spouts (hiti). Hiti were connected to either brick or wooden ducts conveying water through the system of pokhari from a distant source or they were directly supplied with water from a local shallow aquifer. The entire system terminated in an outlet that took water from fountains to drains mostly emptying into the Bagmati River.

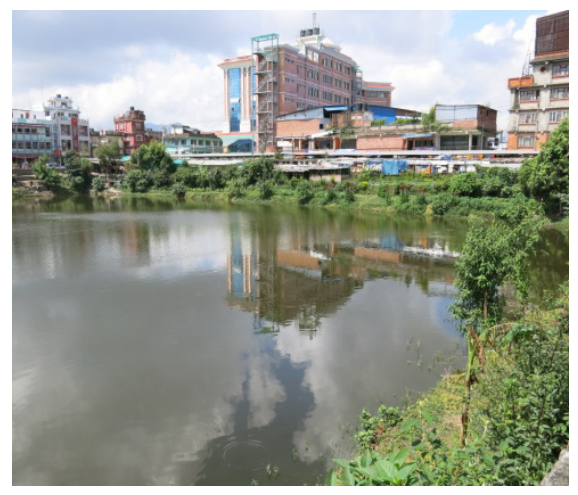

Figure 3: $\quad$ Pokhari in Lagankhel.

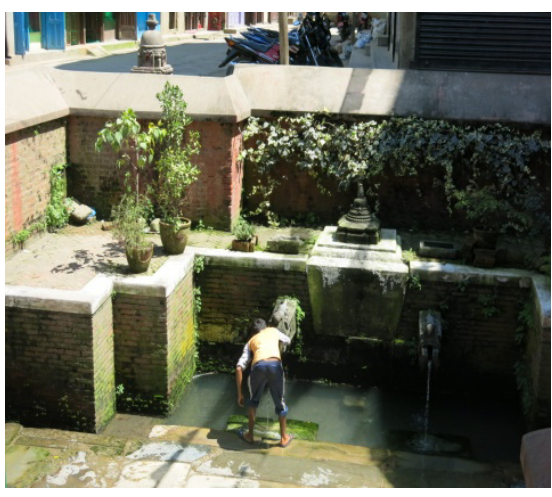

Figure 4: Hiti (Thapa hiti). 
Problems with water supply began in Patan in the 1950s, when the royal dynasty of Nepal was inspired by civilization of the West and throughout Kathmandu and its surroundings, including Patan, started to build water mains. This was accompanied by drying and building up pokharies. During extensive engineering work, when carrying out excavations for the foundations of buildings and construction of sewerage system, some underground ducts supplying hiti were interrupted. The status of water supply in Patan became critical after the year 2006. The central water supply by water mains failed completely along with 4 of 58 hiti in Patan having dried up due to the gradual decline of groundwater level. 7 fountains were fully destroyed due to extensive construction works. Currently, residents of Patan can only rely on water from shallow wells and stone spouts or purchase drinking water from private companies [3].

Tagal hiti and Thapa hiti in the central part of Patan in the past never had a shortage of water that flowed there even in the dry season. But, after destruction of some major pokharies, the groundwater level began to decline and for most of the year the capacity of hiti did not meet the demand of the residents. Local communities joined together and began to solve the situation: they replaced the defunct pokharies in Lagankhel by an alternate source. In 2010, in the area of Nahiti, local communities sank a new storage well with a pumped-storage canal connected to the historical water distribution systems. In this way, they replaced the original source area in Lagankhel and find the new water source for Tagal hiti and Thapa hiti. But, they failed to replace an important infiltration reservoir, that was destroyed (cemented) about 45 years ago - Prayagh pokhari. Currently, there is a school and sports field in this location.

Under the pilot testing of STORAGE project, the rainwater harvesting pilot plant was organized in the Prayag Pokhari area, during August and September 2013. This plant consists from 1 accumulation well (serving to the school, that was without any water source till now) and 2 infiltration pits (that will simulate the original function of artificial water body and enrich groundwater flowing
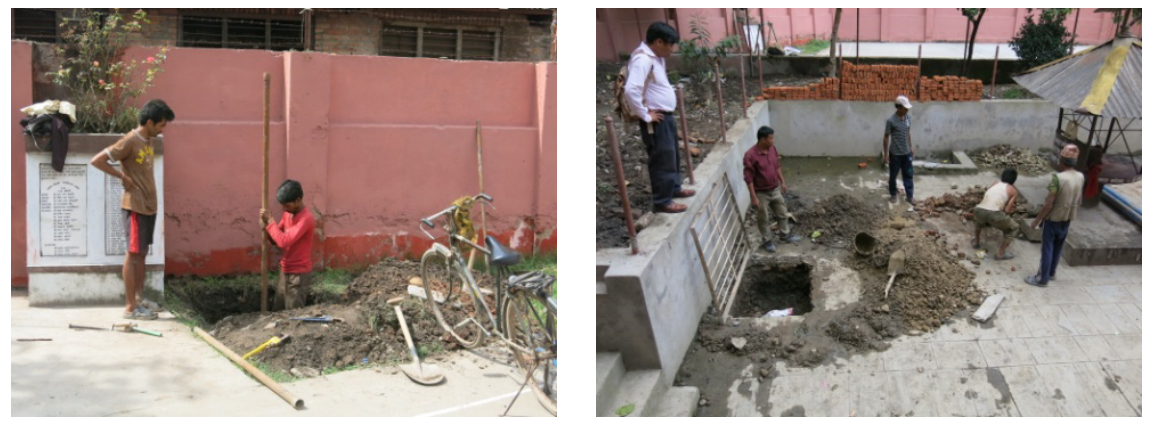

Figure 5: Prayagh pokhari - pit n. 1. Figure 6: Prayagh pokhari - pit n. 2. 
directly to Tagal hiti and Thapa hiti). The first infiltration pit is situated in the former pond, that is now cemented and impermeable. The pit will simulate the earlier infiltration function of pokhari and we will infiltrate there the rain water to the shallow aquifer. The other pit is outside of pokhari, close the wall of the school.

In application of the Prayagh pokhari prototype also in other parts of Patan it would be possible to revive the original water supply system, raise awareness of the local residents of the importance of cooperation and initiate integrated water management at least on a local scale of several neighbouring communities.

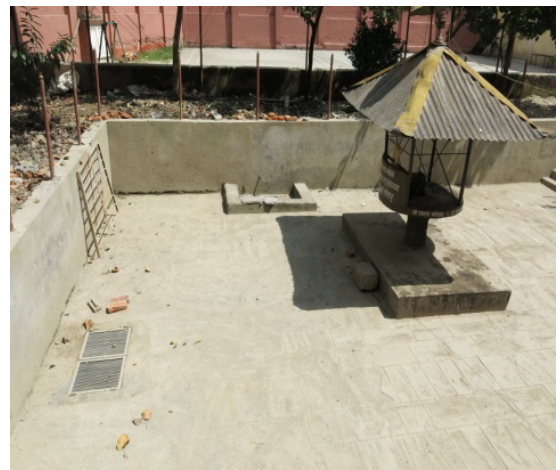

Figure 7: Prayagh pokhari - pit n.2.

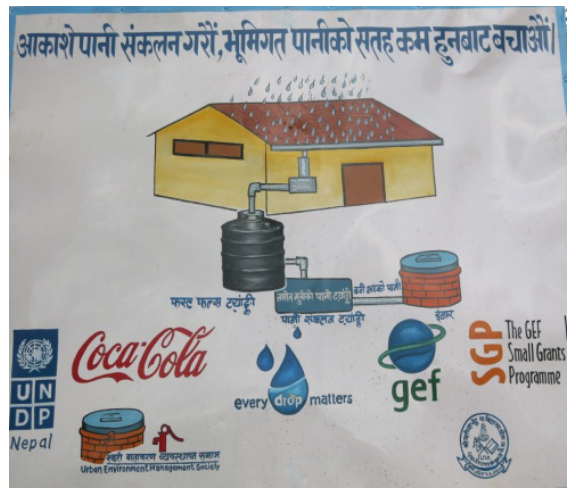

Figure 9: Rainwater harvesting to individual well.

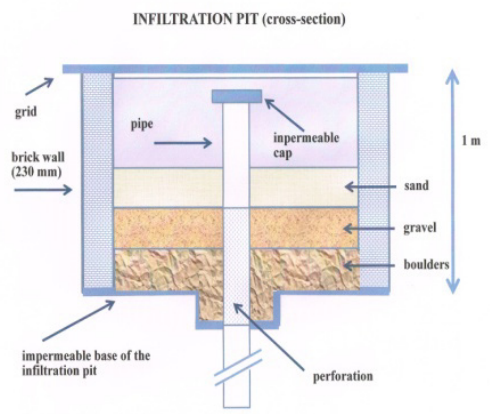

Figure 8: Detail of the pit.

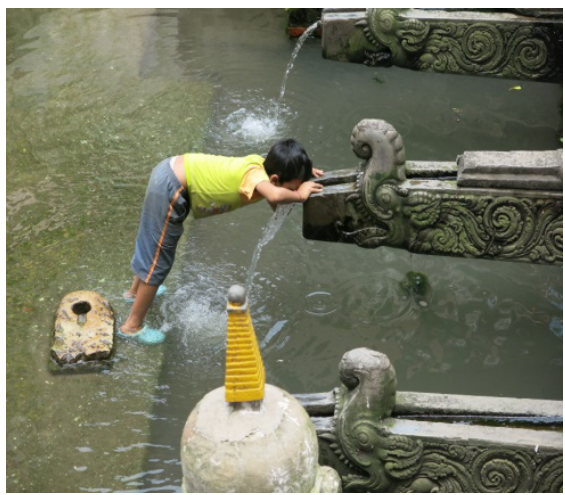

Figure 10: Thapa hiti.

Novelty of the approach in building a pilot plant consists of the infiltration of rainwater not only for local users limited by the area. Pilot plant in Prayagh pokhari is also simulating the original function of artificial water body and will enrich groundwater flowing directly to Tagal hiti and Thapa hiti. Compared to 
the usual approach to the infiltration of rainwater in Patan, where the rainwater from the roof of the building flows to the storage reservoir and from there directly to the local well (see fig. 9), pilot plant in Prayagh pokhari envisages to make use of the filtration potential of the rock environment.

Infiltration of rainwater, as it is presented at the pilot site Prayagh pokhari is one of the possibilities of substituting the defunct or destroyed parts of the historical water supply system and strengthening the capacity of stone spouts.

\section{Conclusions}

Integrated water resource management is based on the perception of water as an integral part of the ecosystem, a natural resource and a social and economic goods, whose quantity and quality determines the nature of its use [4]. With changing climate, the formation and accumulation of water is less predictable, so it is extremely important that the water is used as efficiently as possible. This can be optimally achieved by establishing a tool (Integrated Management for Sustainable Infiltration of Water), which could help the users at the local or regional level to decide whether and how to infiltrate rainwater or treated wastewater in their area, in compliance with all essential legislative, social, environmental and technical procedures.

This tool should be really a technical solution that helps those potentially interested in infiltration of water into the rock aquifer to decide whether and under what conditions is such infiltration possible, convenient and how it meets best all requirements of environmental safety and sustainability. It is a simple application allowing us to explore, on the basis of questions and subsequent answers, the applicability of infiltration of water in the area in question. The draft of this technical solution (integration of environmental and technical, social and legislative conditions) is the task to be completed in the last year of execution of the project STORAGE (2014).

\section{Acknowledgements}

This paper was developed thanks to the E!6731 EUREKA project STORAGE (Sustainable TOols for gRoundwater manAGEment optimisation and water scarcity mitigation), financed by the Ministry of Education, Young and Sports, $\mathrm{CR}$ and the project PROŤĚŽ (Development of advanced technology for environmental protection and incorporation of this knowledge into new tools for better-integrated water management in the catchment scale), financed by the Technology Agency CR.

\section{References}

[1] Parkhurst, D.L., K. G. Stollenwerk, and J. A. Colman. Reactive-Transport Simulation of Phosphorus in the Sewage Plume at the Massachusetts Military Reservation, Cape Cod, Massachusetts. U.S.G.S., 2003. 
[2] Parkhurst, D.L. and C.A.J. Appelo. User's Guide to PHREEQC (Version 2) - A Computer Program for Speciation, Batch-Reaction, One-Dimensional Transport, and Inverse Geochemical Calculations. [Denver]: U.S.G.S., 1999.

[3] Water movement in Patan, Water for Asian Cities Programme Nepal, UNHABITAT, 2008.

[4] Agenda 21 - Protection of the quality and supply of freshwater resources, application of integrated approaches to development, use and management of water resources, programme document of the UN adopted at the conference in Rio de Janeiro in 1992. 